\title{
EVALUATION OF USING EU FUNDING SOURCES IN THE REGIONAL OPERATIONAL PROGRAMMES
} AZ EURÓPAI UNIÓ FEJLESZTÉSI FORRÁSAI FELHASZNÁLÁSÁNAK ÉRTÉKELÉSE A REGIONÁLIS OPERATÍV PROGRAMOK KERETÉBEN

Éva PÁLMAI okl. közgazdász

Address: $\quad 2113$ Erdőkertes, Pálya utca 18.

Phone: $\quad+36-20-571-7936$

E-mail:_epalmai@outlook.hu 
AZ EUROPAI UNIO FEJLESZTESI FORRASAI

\author{
FELHASZNALASANAK ERTEKELESE A REGIONALIS OPERATIV \\ PROGRAMOK KERETEBEN
}

\author{
EVALUATION OF USING EU FUNDING SOURCES IN THE \\ REGIONAL OPERATIONAL PROGRAMMES
}

Keywords: Cohesion policy, territorial cohesion, development policy, application successfulness

\begin{abstract}
Cohesion policy should continue to play a critical role in these difficult times - when Europe need to exit from a deep crisis and reduce unemployment and poverty, while switching to a low-carbon economy - in order to deliver smart, sustainable and inclusive growth, while promoting harmonious development of the Union and its regions by reducing regional disparities. According to most of the reports have been created for the European Commission cohesion policy has made a significant contribution to spreading growth and prosperity across the Union, while reducing economic, social and territorial disparities.

The aim of this study is to identify the results of the efforts of the cohesion policy in the field of reducing territorial disparities: the connection between the social, economic development of the Hungarian regions and the capacity of receiving funding from the Regional Operational Programmes.

As for conclusion of this study for the period 2007-2011, it follows the resource allocation system supported both increasing competitiveness of the developed regions and catching up the less developed regions by reducing regional disparities.
\end{abstract}

Kulcsszavak: regionális politika, területi kohézió, fejlesztéspolitika, pályázati sikeresség

\title{
Kivonat
}

A kohéziós politikának az intelligens, fenntartható és inkluzív növekedés érdekében ezekben a nehéz időkben is alapvető szerepet kell játszania - amikor Európának túl kell lépni egy mély válságon, csökkentenie kell a munkanélküliséget és a szegénységet, ki kell alakítania az alacsony szén-dioxid-kibocsátású gazdaságot -, és a területi egyenlőtlenségek csökkentése révén az Európai Unió és régiói harmonikus fejlődését kell szolgálnia. Az Európai Bizottság számára készített jelentések többsége szerint a kohéziós politika jelentősen hozzájárult a növekedés és jólét Unión belüli terjesztéséhez, valamint a gazdasági, szociális és területi egyenlőtlenségek csökkentéséhez.

A tanulmány célja, hogy képet formáljon az uniós fejlesztéspolitika területi egyenlőtlenségek mérséklésére tett törekvéseinek eredményeiről: a magyarországi térségek társadalmi-gazdasági fejlettsége és a Regionális Operatív Programok keretében történő forráshoz jutási képessége közötti kapcsolatról.

A 2007 és 2011 közötti időszakra vonatkozó elemzésem eredményeképpen megállapítható, hogy a forráselosztási rendszer egyrészt támogatta a fejlettebb térségek versenyképességének erősítését, másrészt a fejletlenek felzárkózását, a területi egyenlőtlenségek enyhítését is.

\section{BEVEZETŐ}

Magyarország 2004. május 1-jén csatlakozott az Európai Unióhoz, és ezt követően jogosulttá vált az EU Strukturális Alapjai és a Kohéziós Alap támogatására. Ezeknek az alapoknak az elsődleges célja az, hogy - a gazdasági és szociális kohézió erősítése 
érdekében - segítsék a tagállamok, valamint régióik közötti fejlettségi különbségek csökkentését. Az Alapok igénybevételéhez a jogosult tagállamoknak Nemzeti Fejlesztési Terv (NFT) keretében ki kellett dolgozniuk és az Európai Bizottság elé terjeszteniük fejlesztési célkitüzéseiket és prioritásaikat. Az NFT egy nemzeti stratégiai dokumentum, melynek hosszú távú célja az életminőség javítása, az adott tervezési időszakhoz kapcsolódó elvárása az egy före jutó GDP EU-átlagához képest mutatkozó elmaradás mérséklése. A célok és a prioritások elérésére kialakított intézkedés együttes a fejlesztés alapját képező öt operatív programban valósult meg ${ }^{63}$. Hazánknak - az Európai Unió az újonnan csatlakozó tagországokra vonatkozó egységes álláspontja alapján - az NFT-ben csak egy regionális program kialakítására volt lehetősége. A program kialakításakor a régiók gyenge érdekérvényesítők voltak. Az egyetlen regionális operatív program a maradék elven épült fel, számos olyan fejlesztési elemet tartalmazott, amit más szektorális programok nem tudtak, vagy akartak befogadni (Rechnitzer - Smahó; 2006; Rechnitzer, 2012). A 2004 és 2006 közötti programozási időszakban a 700 milliárd forint összegű lehívott uniós forrás felhasználása teljes körü volt, azonban a Terv nem minden célja teljesült. Az elmaradottabb régiók felzárkóztatását az NFT csak szerény mértékben segítette, a területileg differenciált támogatási törekvés nem tudta elérni az elmaradottabb régiók kiemelt fejlesztését (Lehmann - Nyers, 2009).

A 2007-2013 közötti programozási periódusban a korábbi ciklussal ellentétben már minden régió tervezhetett uniós finanszírozású Regionális Operatív Programot, melyek kiegészítették az ágazati fejlesztési programokat. A ROP-ok keretében valósulhattak meg többek között a regionális versenyképesség-javítás, a régiók turisztikai potenciáljának, a természeti és kulturális örökségének megőrzése, a közlekedési infrastruktúra-javítás, az energiatakarékosság és hatékonyság ösztönzése, a humán infrastruktúra, a települési infrastruktúra-fejlesztés területén megvalósuló beruházások.

\section{Területfejlesztés a Regionális Operatív Programok keretében}

Magyarország 2007 és 2013 között közel 25 millió euró támogatásban részesült a kohéziós politika forrásaiból. A keretösszeg felhasználásának stratégiai irányelveit és a fejlesztés irányait az Új Magyarország Fejlesztési Terv (ÚMFT) jelölte ki, melynek tizenöt operatív

63 Gazdasági Versenyképesség Operatív Program (GVOP), Humánerőforrás-fejlesztés Operatív Program (HEFOP), Környezetvédelmi és Infrastruktúra Operatív Program (KIOP), Agrár- és Vidékfejlesztési Operatív Program (AVOP) és Regionális Fejlesztési Operatív Program (ROP) 
programja ágazati és regionális szinten fogalmazza meg a felhasználási célokat. A fejlesztési régiók operatív programjaiban 2007 és 2013 között 5,8 millió euró, míg az ágazati operatív programok keretében 19,15 millió euró fejlesztési forrás állt rendelkezésre. Az összegek lehívásának keretrendszerét a Nemzeti Stratégiai Referenciakeret (NSRK) adta. Az NSRK a területi kohézió erősítését fontos horizontális politikaként határozta meg, az Országos Fejlesztéspolitikai Koncepcióban (OFK) és az Országos Területfejlesztési Koncepcióban (OTK) megfogalmazott stratégiai célokra épülve (NFÜ, 2007). Országos célként jelent meg az Európai felzárkózás dimenziója, a belső egyenlőtlenségek csökkentése (regionális és kistérségi léptékben), a területi harmónia szükségessége a fejlesztésekben, valamint a fejlesztések területi szinergiájának igénye (NTH, 2012). Magyarország hét régiója közül a Közép-magyarországi régió (KMR) a korábbi gazdasági mutatói alapján a kohéziós alapok versenyképesség (ún. phasing-in) célkitűzésén belül volt jogosult támogatásra, a többi hat régiónk a konvergencia célkitüzés alá tartozott (NFÜ, 2012). A 2007-2013 időszakra vonatkozó NSRK átfogó céljai a foglalkoztatás bővítése és a tartós növekedés elösegítése voltak. Ezt tükrözték a stratégia számszerűsített céljai is: 120 ezer fővel növekedjen a versenyszféra foglalkoztatotti létszáma és a vállalkozások által megtermelt jövedelem 10\%-kal magasabb legyen. Ezek a célok összhangban voltak az EU lisszaboni stratégiájával, mely a tervezéskor irányadó volt.

A regionális operatív programokban az ágazati programokhoz viszonyítva lényegesen nagyobb hangsúlyt kaptak a területi kohézióhoz kapcsolódó vállalások és célok. Fő céljaikban a regionális felzárkózást (KMR esetében az európai szintü felzárkózást) határozták meg, de az egyes prioritásokhoz kapcsolódóan a területi kohéziós explicit dimenziók is megjelentek. Regionális kompetenciát képeztek a területileg integrált fejlesztések, melyek kiegészítették az ágazati programokban finanszírozott nagytérségi infrastrukturális projekteket és az ágazati fejlesztési programokat. Ide tartoztak a helyi önkormányzatok által ellátandó feladatokhoz kapcsolódó fejlesztések, amelyek szintén térségi és települési integrált akciók keretében végezhetők. Továbbá ide voltak sorolhatók a helyi, térségi versenyelőnyökre építő gazdasági fejlesztések, a regionális gazdasági versenyképesség, az innováció térbeli terjedése és a gazdasági hálózatok fejlesztése, a természeti és kulturális táji adottságok által erősen meghatározott szektorok fejlesztései (NFÜ, 2007).

A szakirodalomban fellelhető számos elemzés az uniós források felhasználását illetően, melyek azonban jellemzően a 2004 és 2006 közötti időszak Nemzeti Fejlesztési Tervének 
keretén belül megvalósuló fejlesztések eredményeit vizsgálták jórészt többváltozós adatelemzési módszerek segítségével. Egyes tanulmányok megállapítják, hogy az EU-s források felhasználása teljes körü volt, forrásallokációs szempontból a területi különbségek csökkentésének irányában hatottak (Lechmann - Nyers, 2009; Lukovics - Lóránd, 2010), más szerzők pedig vitatják a kohéziós politika megvalósításának sikerességét (Lengyel, 2012; Balogh, 2013).

A Nemzeti Fejlesztési Ügynökség (NFÜ) megbízásából az EU-s források területi kohézióra gyakorolt hatásainak vizsgálata céljából készített értékelö jelentések megállapították, hogy a támogatások inkább a területi kohézió erősítése irányába hatottak, ugyanakkor kialakult a fejlesztési területeknek egy olyan szürke zónája, amely a 20072013-as időszakban sem tudott kiemelt szerepet kapni (NFÜ, 2013a; NFÜ 2013b).

\section{CÉLKITŰZÉSEK ÉS MÓDSZEREK}

Területi forrásallokációs elemzésem célja, hogy képet formáljak a Regionális Operatív Programok (ROP) keretében a 2007 és 2011 közötti időszakban a területi egységek fejlesztési forrásokhoz jutási képessége és gazdasági fejlettsége közötti kapcsolatról.

A vizsgálat során a területi dimenziót a projektek fizikai megvalósításának helyszíne jelentette, a területi szinteket pedig a hazai megyék és Budapest. A felhasznált támogatásokra vonatkozó adatok az Országos Területfejlesztési és Településrendezési Információs Rendszerből (TeIR) származnak. A TeIR támogatási alrendszerek moduljába feltöltött adatbázis az elemzés elkészítésekor 2011 novemberéig tartalmazott adatokat, ezért az uniós források felhasználását 2007 és 2011 közötti időszakban vizsgáltam. A vizsgált adatok az egy före jutó költségigény (ezer Ft), az egy före jutó támogatás (ezer Ft) és a projektek száma $(\mathrm{db})$. Az adatbázis aktualizálásán túl további hiányosságként említhető, hogy nem tartalmaz a megvalósult beruházások eredményeire és hatásaira vonatkozó indikátor adatokat, ezért az uniós támogatások felhasználásaival kapcsolatos konkrét eredmények elemzése, valamint a területi mutatókkal történő összevetése, illetve következtetések levonása nem lehetséges. Jelen tanulmányban a pályázati források térbeli elosztását vizsgáltam egy adott időszakra vonatkozóan, melyet összehasonlítottam a területi egységek fejlettségével.

Először a 2007-2011 időszak között megkötött támogatási szerződésekre vonatkozó fajlagos mutatók alapján elkészítettem a megyék rangsorát. A rangsoroláshoz a mutatók 
összevonhatóságának érdekében az emberi fejlettségi index (HDI) elöállítása során is alkalmazott formula alapján képeztem az egyes mutatók indexét.

Index: $\underline{x}_{\underline{i}}-\underline{x}_{\underline{m i n}}$

$\mathrm{X}_{\max }-\mathrm{X}_{\min }$

ahol:

$\mathrm{x}_{\mathrm{i}}$ a változó aktuális értéke

$\mathrm{x}_{\min }$ a változó rögzített minimális értéke

$\mathrm{x}_{\max }$ a változó rögzített maximális értéke

A pályázati sikeresség komplex mutató kiszámítása az alábbiak szerint történt:

1. Egy főre jutó költségigény részindex kiszámítása,

2. Egy före jutó támogatás részindex kiszámítása,

3. Tízezer lakosra jutó projektek száma részindex kiszámítása.

A részindexek kiszámítását követően a területi egységek pályázati sikeresség mértékének összesített indexét a mutatók részindexének átlagolásával kaptam meg. Az eredmények 0 és 1 intervallumú skálán oszlanak meg, a 0 közeli értékek az alacsonyabb, az 1 közeli értékek a magasabb pályázati sikerességü területeket jelölik.

Másodszor sorrendbe állítottam a megyéket fejlettségük alapján. A fejlettség egyetlen jelzőszámmal nem leírható, többdimenziós és többmutatós fogalom, azonban a regionális fejlesztési akciók hatásainak mérésére a legelterjedtebb jelzőszámként a GDP-t alkalmazzák (Nemes Nagy, 1995). Ezért a megyék fejlettségét a 2007. évi és a 2011. évi bruttó hazai termék alapján határoztam meg.

Harmadszor a pályázati sikeresség alapján kialakult rangsort összevetettem a megyék 2007-ben mért egy főre jutó GDP értékeivel. Végül megvizsgáltam a területi folyamatok alakulását a 2007. és 2011. közötti időszakban.

\section{EREDMÉNYEK}

A területi egységek 2007-2011 közötti ROP-ok keretében lehívott források vizsgálatát illetően az 1. táblázatban látható eredmények alakultak ki. A relatíve magas pályázati sikerességű megyék közé tartozik a főváros mellett Baranya és Csongrád megye. Az átlagos pályázati teljesítménnyel jellemezhető megyék a következők: Pest, Somogy, 
Heves, Borsod-Abaúj-Zemplén, Vas és Veszprém. A relatíve alacsony pályázati sikerességű megyék pedig Bács-Kiskun, Békés, Győr-Moson-Sopron, Hajdú-Bihar, JászNagykun-Szolnok, Komárom-Esztergom, Nógrád, Szabolcs-Szatmár-Bereg, Tolna és Zala megye.

1. táblázat: A megyék rangsora pályázati sikerességük alapján 2007-2011

\begin{tabular}{|l|c|}
\hline \multicolumn{1}{|c|}{ Megye, föváros } & Index \\
\hline Baranya & 0,99 \\
\hline Budapest & 0,91 \\
\hline Csongrád & 0,74 \\
\hline Pest & 0,63 \\
\hline Somogy & 0,60 \\
\hline Heves & 0,52 \\
\hline Borsod-Abaúj-Zemplén & 0,51 \\
\hline Vas & 0,42 \\
\hline Veszprém & 0,42 \\
\hline Hajdú-Bihar & 0,27 \\
\hline $\begin{array}{l}\text { Szabolcs-Szatmár- } \\
\text { Bereg }\end{array}$ & 0,24 \\
\hline Zala & 0,17 \\
\hline Jász-Nagykun-Szolnok & 0,15 \\
\hline Tolna & 0,15 \\
\hline Nógrád & 0,10 \\
\hline Békés & 0,06 \\
\hline Fejér & 0,05 \\
\hline Bács-Kiskun & 0,05 \\
\hline Györ-Moson-Sopron & 0,05 \\
\hline Komárom-Esztergom & 0,01 \\
\hline Forrás: saját szerkesztés & \\
\hline
\end{tabular}

A megyék egy főre jutó GDP alapján meghatározott fejlettségi szintje a 2007. évre vonatkozóan az alábbiak szerint alakul.

2. táblázat: A megyék rangsora az egy főre jutó GDP alapján 2007

\begin{tabular}{|l|c|}
\hline \multicolumn{1}{|c|}{ Megye, föváros } & $\begin{array}{c}\text { 2007 (ezer } \\
\text { Ft) }\end{array}$ \\
\hline Budapest & 5355 \\
\hline Györ-Moson-Sopron & 2811 \\
\hline Komárom-Esztergom & 2708 \\
\hline Fejér & 2382 \\
\hline Pest & 2313 \\
\hline Vas & 2254 \\
\hline Zala & 2009 \\
\hline Veszprém & 1850 \\
\hline Csongrád & 1806 \\
\hline
\end{tabular}


2. táblázat (folytatás)

\begin{tabular}{|l|c|}
\hline \multicolumn{1}{|c|}{ Megye, fóváros } & $\begin{array}{c}\text { 2007 (ezer } \\
\text { Ft) }\end{array}$ \\
\hline Heves & 1784 \\
\hline Hajdú-Bihar & 1772 \\
\hline Baranya & 1767 \\
\hline Tolna & 1742 \\
\hline Bács-Kiskun & 1637 \\
\hline $\begin{array}{l}\text { Borsod-Abaúj- } \\
\text { Zemplén }\end{array}$ & 1631 \\
\hline Jász-Nagykun-Szolnok & 1601 \\
\hline Somogy & 1561 \\
\hline Békés & 1468 \\
\hline $\begin{array}{l}\text { Szabolcs-Szatmár- } \\
\text { Bereg }\end{array}$ & 1336 \\
\hline Nógrád & 1143 \\
\hline
\end{tabular}

Forrás: saját szerkesztés

Budapest kimagasló adata után az átlagosnál fejlettebb megyék közé tartozik Győr-MosonSopron, Komárom-Esztergom, Fejér, Pest, Vas és Zala megye, a többi megye a relatíve alacsony fejlettségű megyék kategóriájába tartozik. Amennyiben összehasonlítjuk a megyék és a főváros pályázati sikerességi és fejlettségi rangsorát, megállapítható, hogy Budapestet és Pest megyét kivéve a fejlettségi rangsorban elért előkelő helyezés általában a pályázati sikeresség rangsorban kevéssé előkelő helyezéssel párosult. A területi folyamatok alakulása megfigyelése érdekében a 2011. évre vonatkozóan is elkészítettem a megyék rangsorát az egy före eső GDP alapján.

3. táblázat: A megyék rangsora az egy főre eső GDP alapján 2011

\begin{tabular}{|l|c|}
\hline \multicolumn{1}{|c|}{ Megye, föváros } & 2011 (ezer Ft) \\
\hline Budapest & 6096 \\
\hline Győr-Moson-Sopron & 3414 \\
\hline Komárom-Esztergom & 2804 \\
\hline Fejér & 2573 \\
\hline Vas & 2453 \\
\hline Pest & 2340 \\
\hline Zala & 2210 \\
\hline Tolna & 2088 \\
\hline Hajdú-Bihar & 2049 \\
\hline Csongrád & 2005 \\
\hline Veszprém & 1951 \\
\hline Bács-Kiskun & 1873 \\
\hline Heves & 1871 \\
\hline Jász-Nagykun-Szolnok & 1780 \\
\hline Baranya & 1773 \\
\hline
\end{tabular}


3. táblázat (folytatás)

\begin{tabular}{|l|l|}
\hline Somogy & 1758 \\
\hline Borsod-Abaúj-Zemplén & 1672 \\
\hline Békés & 1558 \\
\hline Szabolcs-Szatmár-Bereg & 1476 \\
\hline Nógrád & 1222 \\
\hline
\end{tabular}

Forrás: saját szerkesztés

Továbbra is a legfejlettebb megyék közé tartozik a főváros kiemelkedő adata után GyőrMoson-Sopron, Komárom-Esztergom, Fejér, Vas, Pest, és Zala megye, valamint a legkevésbé fejlett megyék közé sorolható Békés, Szabolcs-Szatmár-Bereg és Nógrád megye. Ugyanakkor Csongrád, Veszprém, Heves, Baranya és Borsod-Abaúj-Zemplén megyék esetében visszaesés, Tolna, Hajdú-Bihar, Bács-Kiskun, Jász-Nagykun-Szolnok és Somogy megyéket illetően pedig relatív fejlődés tapasztalható 2007 és 2011 között.

\section{AZ EREDMÉNYEK ÉRTÉKELÉSE}

A pályázati sikeresség szempontjából a forráselosztási rendszer nem mutat egységes képet. A fejletlenebb régiók közül a vizsgált időszakban az Észak-magyarországi régióban Heves és Borsod-Abaúj-Zemplén megye sorolható a közepes pályázati sikerességü megyék közé. Nógrád megye fejlesztési szükségletéhez képest lényegesen kevesebb forráshoz jutott, ennek oka, hogy kistérségei általában a leghátrányosabb helyzetü kistérségek közé tartoznak, de nem kerültek be a komplex programmal segítendö kistérségek közé. Hasonlóan alakult a Dél-dunántúli régió helyzete is, itt Baranya megye generált többletforrás felhasználást a „Pécs Európa Kulturális Fővárosa 2010” című projekt megvalósításával, valamint a Dél-alföldi régió pályázati sikeressége, ahol Csongrád megyében Szeged valósított meg nagy értékủ beruházásokat, mint például az Újszegedi Fürdőkomplexum Fejlesztése kiemelt projektet. Meglepő, hogy a fejlettebb régiókban a pályázati sikeresség a várthoz képest szintén vegyes képet mutat, a legfejlettebb GyőrMoson-Sopron megye elmarad a nála fejletlenebb Vas és Veszprém megyétől. A Középmagyarországi régió 2011 végéig történt magas forráslehívása elsősorban az agglomerációs településeken jelent meg.

A gazdasági teljesítmény mérésére szolgáló egy före jutó bruttó hazai termék tekintetében 2011-ben a központi régió és a konvergencia régiók összehasonlításában Közép-Magyarországon továbbra is több, mint másfélszer akkora volt az egy före jutó GDP, mint a rangsorban őt követő Közép- vagy Nyugat-Dunántúl esetén, és két és félszerese a további négy régiónak. Megyei összehasonlításban Budapest kiemelkedő adata 
mellett Győr-Moson-Sopron és Komárom-Esztergom, Fejér, Vas, Pest megye gazdasági teljesítménye haladta meg az országos átlagot. Az egy főre jutó GDP Nógrád, SzabolcsSzatmár-Bereg és Békés megyékben volt a legalacsonyabb a vizsgált években.

\section{KÖVETKEZTETÉSEK}

A források területi elosztását illetően leszerződött támogatási összeg, az összköltség egy főre jutó értéke, valamint a tízezer lakosra jutó projektek száma a 2007 és 2011 közötti időszakban a konvergencia régiókban csupán a Dél-dunántúli és az Észak-magyarországi régióban volt magasabb az országos átlagnál. Nincs közvetlen összefüggés az egyes régiók fejlettségi szintje és a források lehívásának gyorsasága között, ami a fejletlenebb régiók hátrányának csökkentése szempontjából stratégiailag lényeges lépés lett volna. Megállapítható, hogy a forráselosztási rendszer egyrészt támogatta a fejlettebb térségek versenyképességének erősítését (itt volt magasabb a pályázati sikeresség), és részben a fejletlenek felzárkózását, a területi egyenlőtlenségek enyhítését is.

Az ÚMFT által kitűzött célokat a vizsgált időszak végéig hazánknak nem sikerült elérni, melyben döntő szerepet játszott a 2008-ban kirobbanó gazdasági világválság is, mely hazánkat legyengült állapotában különösen súlyosan érintette. Mindezekhez hozzájárult az elmúlt évtizedben rohamos mértékben növekvő és magas szintet elérő államadósság, a költségvetési hiány, valamint az ország kedvezőtlen makrogazdasági szerkezete. A recesszióból csak 2010 során sikerült kikerülni. A kohéziós politika mellett nélkülözhetetlen a belső divergencia csökkentését is kezelő nemzeti politika, amely a kormányzati célokkal és elvárásokkal összhangban a források szabályos lekötésén túl a megvalósított fejlesztések társadalmi, gazdasági hasznosulását is szem előtt tartja.

A megvalósult fejlesztések tényleges hatásának mérésére és megfelelő következtetések levonására jelen tanulmány keretében nem volt lehetőség, mivel egyrészt a projektek befejezését követő hosszabb idő elteltére, másrészt az elemzés céljának megfelelően feltöltött és rendelkezésre bocsátott adatbázisra lenne szükség, továbbá olyan értékelési módszertan kialakítására, mely kiszüri a fejlesztéspolitikai intézkedések mellékhatásait is.

\section{SUMMARY}

Hungary was entitled to receive approximately EUR 25 million euro development funds from the cohesion policy of the EU between 2007 and 2013, which was supplemented by national co-financing and private capital. The National Strategic Reference Framework (NSRF) has outlined the strategic guidelines of the usage of this amount and also assigned the directions of development. Its fifteen operational programs have defined the goals of the use at sectorial and regional level. The available fund for developments implemented 
in the regional operational programs was EUR 5.8 million, while for projects in the sectorial operational programmes was EUR 19.15 million between 2007 and 2013.

The aim of this study is to identify the results of the efforts of the cohesion policy in the field of reducing territorial disparities between 2007 and 2011: the connection between the social, economic development of the Hungarian regions and the capacity of receiving funding from the Regional Operational Programmes (ROP) of NSRF.

During the analysis the territorial dimension was the physical location of the projects, and the territorial levels were the national counties and Budapest. Data, relating to the subsidies used, were taken from the National Spatial development and Settlement planning Information System. I have examined the evaluation of EU funds between 2007 and 2011. The data analysed: the total cost per capita (thousand HUF), the amount of contracted per capita (thousand HUF), the number of projects per ten thousand populations (piece).

Firstly the counties were ranked based on the specific indicator concerning the contracts concluded between 2007 and 2011 with the method of calculating the Human Development Index (HDI). Secondly the counties were sorted by gross domestic product (GDP) per capita in the years 2007 and 2011, the indicator used for the spatial comparison of the level of economic development. Thirdly the ranking created from the application successfulness was compared to the development level of the counties measured by GDP per capita in 2007. Finally the regional processes were examined in the period between 2007 and 2011.

As the result of the examination of the resource allocation in the framework of ROP between 2007 and 2011 developed as follows: beside the capital city, Baranya and Csongrád counties have the relative high level of the application successfulness. Pest, Somogy, Heves, Borsod-Abaúj-Zemplén, Vas and Veszprém counties have average level of the application successfulness. Bács-Kiskun, Békés, Győr-Moson-Sopron, HajdúBihar, Jász-Nagykun-Szolnok, Komárom-Esztergom, Nógrád, Szabolcs-Szatmár-Bereg, Tolna and Zala counties have low level of the application successfulness.

Based on GDP per capita, the development level of the regional units in 2007 developed as follows. Following the outstanding performance of Budapest the more developed counties are Györ-Moson-Sopron, Komárom-Esztergom, Fejér, Pest, Vas és Zala. The rest of the counties fall under the relative less developed counties. If we compare the ranking of the application successfulness of the counties and the capital city, it follows that, excluding Budapest and Pest County, high place in the ranking of application successfulness is assured in conjunction with low place in the ranking.

In order to observe the spatial processes the counties were ranked based on GDP per-capita also for the year 2011. Following the outstanding value of the capital city, Győr-Moson-Sopron, Komárom-Esztergom, Fejér, Vas, Pest, és Zala are still the most developed counties. Békés, Szabolcs-Szatmár-Bereg and Nógrád are the least developed counties, as in the year 2007. However Csongrád, Veszprém, Heves, Baranya and Borsod counties have declined, Tolna, Hajdú-Bihar, Bács-Kiskun, Jász-Nagykun-Szolnok and Somogy counties have relative developed between 2007 and 2011.

Based on GDP per capita comparing the central and the convergence regions in 2011, GDP per capita in Central Hungary was 1.5 times the value of Central or West Transdanubia and it was 2.5 times the value of the other four regions. Comparing the counties besides the best performing Budapest the value for GyörMoson-Sopron, Komárom-Esztergom, Fejér, Vas, Pest County was higher than the national average level. In the reviewed period the value of GDP per capita was the lowest in Nógrád, Szabolcs- Szatmár-Bereg és Békés counties. The value for the capital is five times higher than of Nógrád County, which is in the last position in the ranking of the counties.

The resource allocation system does not show homogeneity from the aspect of application successfulness. Regarding the regional distribution of funds the amount of contracted grants, the total cost per capita and the number of projects per ten thousand populations, were higher than the national average only in the South Transdanubia and in the Northern Hungarian regions between 2007 and 2011 in the convergence regions. There is no direct correlation between the development level of the regions and their capacity of receiving funding, which would have been a strategically important step in order to reduce the disadvantage of the less developed regions. As for conclusion of this study for the period 2007-2011, it follows that the resource allocation system on the one hand supported the strengthening of the competitiveness of the developed regions (where application successfulness was higher) and on the other it helped catching up the less developed regions by reducing regional disparities.

\section{IRODALOM}

Balogh, P. (2013). „A racionálistól a részvételig”. Redisztribúció, területi gazdálkodás, területfejlesztési politika átalakulóban Magyarországon. Belvedere Meridionale. XXV.3.51-67. p 
Lehmann, K., Nyers, J. (2009). Az Európai Unió fejlesztési forrásainak felhasználása. Statisztikai Szemle, 87. évfolyam 2. szám, 139-141. p.

Lengyel, I. (2012). A hazai területfejlesztés zsákutcái: a triális Magyarország, http://www.regscience.hu:8080/jspui/bitstream//11155/127/3/Rechnitzer_2012_dialo gus.pdf\#page=141 (letöltés ideje: 2014. május 20.)

Lóránd, B. (2009). A fejlesztéspolitika sikerességét elősegítő tényezők és a kohéziós országok tapasztalatai Magyarország számára. Tér és Társadalom 23. évf. 2009/2. 213-214.p

Lukovics, M., Lóránd, B. (2010). A versenyképesség és pályázati forrásallokáció kistérségi szinten, Tér és Társadalom XXIV. évf. 97. p

Nemes Nagy, J. (1995). A GDP regionális számbavétele. In: Probáld F. szerk. Pro Geographia Humana, ELTE Eötvös Kiadó, Bp. pp. 99-118.

NFÜ (2003). Nemzeti Fejlesztési Terv, http://www.nfu.hu/doc/128, (Letöltés ideje: 2014. január 10.)

NFÜ (2007). Új Magyarország Fejlesztési Terv, http://www.nfu.hu/doc/109 (Letöltés ideje: 2014. január 10.)

NFÜ (2012). Nemzeti Stratégiai Jelentés, http://ec.europa.eu/regional_policy/how/policy/ doc/strategic_report/2012/hu_strat_report_2012.pdf (Letöltés ideje: 2014. január 15.)

NFÜ (2013a). Végső értékelési jelentés, http://www.nfu.hu/az_eu_s_tamogatasok_teruleti koheziora_gyakorolt hatasainak_ertekelese (Letöltés ideje: $\overline{2} 014$. január 15.)

NFÜ (2013b). Értékelési évkönyv, http://hetfa.hu/2013/10/ertekelesi-evkonyv-2013/ (Letöltés ideje: 2014. május 20.)

NTH (2012). JELENTÉS az ország területi folyamatainak alakulásáról, a területfejlesztési politika és a területrendezési tervek érvényesítésének hatásairól, az Országos Területfejlesztési Koncepció felülvizsgálatáról, valamint a magyar településhálózat helyzetéről. http://www.nth.gov.hu/elemzes_ertekeles/index.html (Letöltés ideje: 2014. január 15.)

Országos Fejlesztéspolitikai Koncepció (2005). http://www.terport.hu/teruletfejlesztes/ orszagos-szint/fejlesztesi-dokumentumok/orszagos-fejlesztespolitikai-koncepcio (Letöltés ideje: 2014. január 10.)

Országos Településfejlesztési Koncepció (2005). http://www.kormany.hu/download/8/17/ 90000/OTK2005hun.pdf (Letöltés ideje: 2014. január 10.)

Rechnitzer, J. (2012). A régiók az elmúlt 20 év területi politikájában. In: Bajmóczy Z., Lengyel, I., Málovics, Gy. (szerk). Regionális innovációs képesség, versenyképesség és fenntarthatóság. JATEPress, Szeged, 187. p.

Rechnitzer, J., Smahó, M. (2006). Regionális politika. Győr, Széchenyi István Egyetem. 173. p. 1 